\title{
Novel, Selective Vitamin D Analog Suppresses Parathyroid Hormone in Uremic Animals and Postmenopausal Women
}

\author{
Julia B. Zella ${ }^{a}$ Lori A. Plum ${ }^{a}$ David R. Plowchalk ${ }^{c}$ Michael Potochoiba ${ }^{b}$ \\ Margaret Clagett-Dame ${ }^{a}$ Hector F. DeLuca ${ }^{a}$ \\ a Department of Biochemistry, University of Wisconsin-Madison, and Deltanoid Pharmaceuticals, Inc., bepartment of Drug \\ Metabolism, Covance, Madison, Wisc., and ${ }^{\mathrm{C} C l i n i c a l}$ Pharmacology, Primary Care, Pfizer, Groton, Conn., USA
}

\section{Key Words}

Secondary hyperparathyroidism $\cdot$ Renal failure .

Vitamin D-based therapy

\begin{abstract}
Background: The use of 1a-hydroxylated vitamin D therapy to control secondary hyperparathyroidism in renal failure patients has been a success story, culminating with the demonstration of increased life expectancy in patients treated with these compounds. However, hypercalcemic episodes have been a recurrent problem with these therapies and have resulted in the added use of calcium mimetics. Clearly there is good reason to search for improved vitamin $D$ therapy. In our inventory of vitamin D compounds, 2-methylene19-nor-(20S)-1a,25-dihydroxyvitamin $\mathrm{D}_{3}$ (2MD) surfaced as a potential candidate. This was based on its preferential localization in the parathyroid gland and a clear suppression of serum parathyroid hormone (PTH) levels without a change in serum calcium in a clinical trial in postmenopausal women. Methods: 2MD has now been tested in the rat 5/6-nephrectomy model of renal failure, and in postmenopausal women to determine if it can suppress serum PTH at doses that do not elevate serum calcium and serum phosphorus concentrations. Results: Daily oral treatment of uremic rats on $2.5 \mathrm{ng} / \mathrm{bw} /$ day of $2 \mathrm{MD}$ dramatically suppressed PTH with-
\end{abstract}

out a change in serum calcium or serum phosphorus. Further, PTH was suppressed in postmenopausal women after only 3 daily oral doses of $2 \mathrm{MD}$ that continued for 4 weeks with no change in serum calcium or serum phosphorus. Conclusion: These results coupled with a pharmacokinetic halflife of $\sim 24 \mathrm{~h}$ suggest that $2 \mathrm{MD}$ given either daily or at the time of dialysis may be a superior therapy for secondary hyperparathyroidism in chronic renal failure patients.

() 2014 S. Karger AG, Basel

\section{Introduction}

The treatment of renal osteodystrophy with a vitamin D compound was initiated by Stanbury's group before the discovery of the vitamin $\mathrm{D}$ endocrine system [1]. The discovery of 25 -hydroxyvitamin $\mathrm{D}_{3}\left(25-\mathrm{OH}-\mathrm{D}_{3}\right)$ as an active metabolite of vitamin D [2] led to its application in the treatment of bone diseases secondary to renal failure as the drug, Calderol ${ }^{\circledR}$ (Upjohn and Organon in the United States and Dedrogyl ${ }^{\circledR}$ by Roussel Uclaf in Europe) $[3,4]$. With radiolabeled $25-\mathrm{OH}-\mathrm{D}_{3}$ came the realization that $25-\mathrm{OH}-\mathrm{D}_{3}$ is rapidly metabolized to a highly potent metabolite that was isolated and identified as $1 \alpha, 25$-dihydroxyvitamin $\mathrm{D}_{3}\left(1,25-(\mathrm{OH})_{2} \mathrm{D}_{3}\right)$ [5]. Fraser and Kodicek [6] further demonstrated that the

\begin{tabular}{ll}
\hline KARGER & $\begin{array}{l}\text { ( ) 2014 S. Karger AG, Basel } \\
0250-8095 / 14 / 0396-0476 \$ 39.50 / 0 \quad \text { Karger }\end{array}$ \\
$\begin{array}{l}\text { E-Mail karger@karger.com } \\
\text { www.karger.com/ajn }\end{array}$ & $\begin{array}{l}\text { This is an Open Access article licensed under the terms of the } \\
\text { Creative Commons Attribution-NonCommercial 3.0 Un- } \\
\text { ported license (CC BY-NC) (www.karger.com/OA-license), } \\
\text { applicable to the online version of the article only. Distribu- } \\
\text { tion permitted for non-commercial purposes only. }\end{array}$
\end{tabular}

Dr. Hector F. DeLuca

Department of Biochemistry

University of Wisconsin-Madison

433 Babcock Drive, Madison, WI 53706-1544 (USA)

E-Mail deluca@ biochem.wisc.edu 
1a-hydroxylation takes place in the kidney that was quickly confirmed [7]. Experiments demonstrating that $1,25-(\mathrm{OH})_{2} \mathrm{D}_{3}$ and not $25-\mathrm{OH}-\mathrm{D}_{3}$ is the active form of vitamin $\mathrm{D}$ for calcium and phosphorus homeostasis brought about the realization that a lack of $1,25-(\mathrm{OH})_{2} \mathrm{D}_{3}$ might be responsible for renal osteodystrophy $[8,9]$. As soon as synthetically produced $1,25-(\mathrm{OH})_{2} \mathrm{D}_{3}$ became available as Rocaltrol ${ }^{\circledR}$, it became the treatment of choice without fully realizing its mode of action $[10,11]$. The discovery of the vitamin D receptor $[12,13]$ was soon followed by the finding that the parathyroid gland is a prime target of 1,25- $(\mathrm{OH})_{2} \mathrm{D}_{3}$ regulating the production and secretion of parathyroid hormone (PTH) [14-16]. At last it became clear that the prime result of the vitamin D therapies in renal patients is the suppression of secondary hyperparathyroidism $[15,16]$. A side effect of therapy with oral $1,25-(\mathrm{OH})_{2} \mathrm{D}_{3}$ is hypercalcemia resulting from increased intestinal calcium absorption and bone calcium mobilization [17]. Intravenous $1,25-(\mathrm{OH})_{2} \mathrm{D}_{3}$ $\left(\right.$ Calcijex ${ }^{\circledR}$ ) was a clear improvement bypassing the 'firstpass' effect of oral $1,25-(\mathrm{OH})_{2} \mathrm{D}_{3}$ on intestine [17]. $1 \alpha$-Hydroxyvitamin $\mathrm{D}_{2}$ and $1 \alpha$-hydroxyvitamin $\mathrm{D}_{3}$ require 25-hydroxylation in the liver before becoming active. They also represent an improvement over Rocaltrol ${ }^{\circledR}$ by avoiding first-pass effect on calcium absorption from the intestine $[18,19]$. Two analogs, 19-nor-1 $\alpha$, 25-dihydroyvitamin $\mathrm{D}_{2} \quad[20]$ and 22-oxa-1a,25dihydroxyvitamin $\mathrm{D}_{3}[21]$, were introduced with reduced calcemic activity that appeared to provide a wider therapeutic window. Vitamin $\mathrm{D}$ treatments in general and 19-nor-1a,25-dihydroxyvitamin $\mathrm{D}_{2}\left(\right.$ Zemplar $\left.^{\circledR}\right)$ in particular increase the life expectancy of chronic kidney disease (CKD) patients [22].

Another analog, 2-methylene-19-nor-(20S)-1a,25dihydroxyvitamin $\mathrm{D}_{3}(2 \mathrm{MD})$ with bone anabolic activity was being developed for the treatment of osteoporosis [23]. This highly potent analog also possesses increased bone-mobilizing activity [23]. In postmenopausal women, this analog did not increase bone mass but increased both bone synthesis and bone resorption biomarkers [24]. Importantly, it markedly suppressed circulating PTH levels in these patients without changing serum calcium levels. Furthermore, distribution studies conducted in rats, showed a strong localization of $2 \mathrm{MD}$ to the thyro/ parathyroid gland. The possible usefulness of $2 \mathrm{MD}$ in the treatment of secondary hyperparathyroidism of renal failure seemed compelling. We have carried out a number of studies in the 5/6-nephrectomy rat model of CKD and find that $2 \mathrm{MD}$ is a potent suppressor of secondary hyperparathyroidism and appears to have a wide thera- peutic window. In addition, clinical trials done in postmenopausal women provide encouraging pharmacodynamic and pharmacokinetic results indicating that $2 \mathrm{MD}$ will work as an oral therapy for patients with secondary hyperparathyroidism. This paper provides these results.

\section{Methods}

Whole-Body Autoradioluminography (WBAL) in Rats

The tissue distribution of $2 \mathrm{MD}$ was studied using tritium-labeled 2MD (one tritium incorporated at carbons 9 and 11 of the D ring). The specific activity was $54 \mathrm{Ci} / \mathrm{mmol}$ and radiochemical purity as assessed by HPLC was $98 \%$. Male Long-Evans rats were given one single oral dose of radiolabeled $2 \mathrm{MD}(1.9 \mu \mathrm{g} / \mathrm{kg}$ or 247 $\mu \mathrm{Ci} / \mathrm{kg}$ ) mixed in Neobee M-5 oil. One rat was euthanized by $\mathrm{CO}_{2}$ asphyxiation at $1,2,4,8,12,24,72$, or $168 \mathrm{~h}$ after the dose was administered. Euthanized rats were prepared for WBAL by immersion in a hexanes/dry ice bath for $10 \mathrm{~min}$. Quantification of the cryosection images was done as previously described $[25,26]$. The lower limit of quantitation was $0.2 \mathrm{ng}$ equivalent hormone/g tissue.

\section{Uremic Rat Studies}

Male weanling Sprague-Dawley rats were purchased from Harlan Laboratories (Indianapolis, Ind., USA). On arrival, animals were allowed access to water and standard rodent chow (LabDiet ${ }^{\circledR}$ Rat Diet 5012; LabDiet, St. Louis, Mo., USA) ad libitum. Throughout the study, the animals were maintained in temperature- $(21.1-$ $22.2^{\circ} \mathrm{C}$ ) and humidity- (40-50\%) controlled rooms under a $12 \mathrm{~h}$ light $/ 12 \mathrm{~h}$ dark cycle. All work was conducted under protocols reviewed and approved by a University of Wisconsin-Madison Institutional Animal Care and Use Committee (Protocol No. A01192).

After 1 week of acclimatization, rats underwent a two-stage subtotal nephrectomy to produce a uremic state. The first surgery was done to remove two thirds of the renal mass of the left kidney by pole ligation. The second surgery was done 1 week later and a ligature was placed around the renal hilum of the right kidney and the entire renal mass was excised. Pain was managed with pre- and postoperative subcutaneous injections of buprenorphine $(0.05 \mathrm{mg} / \mathrm{kg})$.

Immediately after the second surgery, rats were switched to a purified diet containing $0.6 \%$ calcium and $0.9 \%$ phosphorus [20]. After 4 weeks, the rats had elevated parathyroid hormone levels and were randomized into treatment groups by their baseline iPTH values. Any rat with an iPTH $<100 \mathrm{pg} / \mathrm{ml}$ was considered unsuccessful in developing secondary hyperparathyroidism and, therefore, excluded from the study. Dosing solutions were delivered to the back of the tongue using a Hamilton syringe fitted with a bluntended needle covered in Tygon tubing. Rats received vehicle or vitamin $\mathrm{D}$ analogs each morning for 8 weeks. In addition to baseline, blood collections were also performed after both 4 and 8 weeks of treatment.

All blood collections were performed within the first $6 \mathrm{~h}$ of the vivarium's light cycle. Rats were sedated with ether and blood was sampled from the tail artery. Blood draws that occurred during treatment with study drug were performed approximately $24 \mathrm{~h}$ after the previous dose. iPTH levels were measured in serum by ELISA (Immutopics, Inc., San Clemente, Calif., USA). Serum calcium levels were measured in $0.1 \%$ lanthanum chloride by atomic 
Fig. 1. Tissue distribution of ${ }^{3} \mathrm{H}-2 \mathrm{MD}$ in Long-Evans rats. Each bar represents 1 rat. $2 \mathrm{MD}$ radioequivalents ( $\mathrm{ng} \mathrm{Eq} / \mathrm{g}$ ) were determined by averaging the concentration of radioactivity from multiple sections. $\mathrm{NT}=$ Not taken, i.e. an evaluable sample was not obtained.

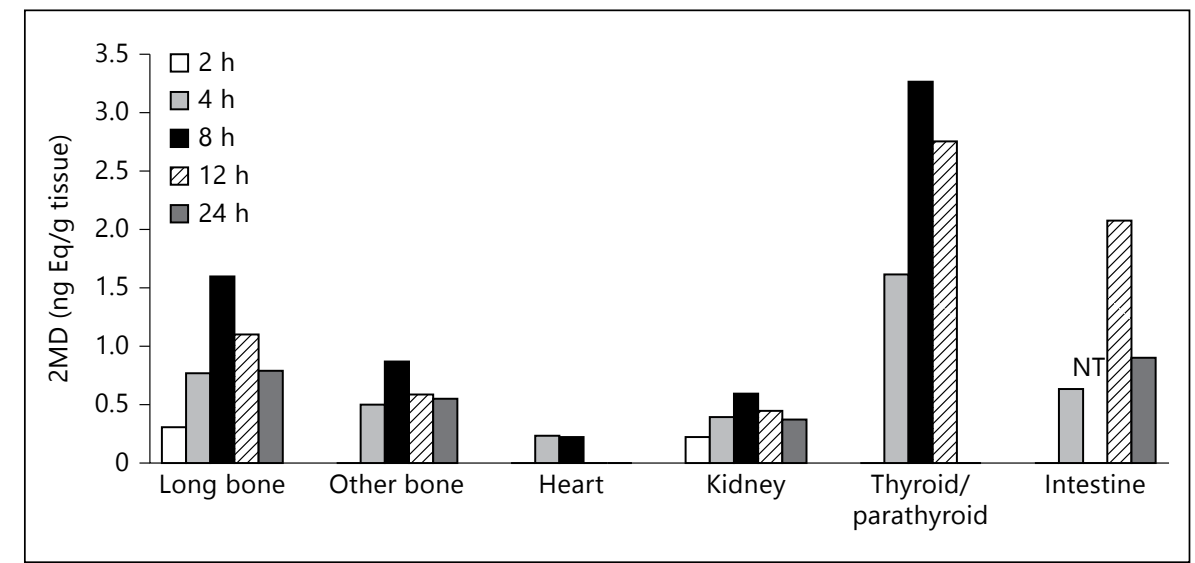

absorption spectroscopy (Perkin-Elmer Spectrometer, Model 3110). Both serum phosphorus and serum creatinine were measured with a clinical chemistry benchtop analyzer (ABX Pentra 400; Horiba Medical) using reagents purchased from HORIBA ABX Diagnostics (Irvine, Calif., USA).

Postmortem whole-body bone mineral densitometry was performed using DEXA (Hologic QDR 80191).

The vehicle for all oral formulations was $5 \%$ ethanol in Neobee M-5 oil (Spectrum). Neobee M-5 oil was measured gravimetrically. The $2 \mathrm{MD}$ was determined to be $>99 \%$ pure by HPLC analysis. $2 \mathrm{MD}$ concentrations in ethanol were measured by UV spectrometry using a molar extinction coefficient $=42,000$ at $252 \mathrm{~nm}$. Dosing solutions were formulated to be delivered at $0.5 \mathrm{ml} / \mathrm{kg} \mathrm{bw}$. The actual volume of dosing solution delivered to each rat was based on individual body weight and adjusted weekly.

Phase 1B Dose-Finding Study in Postmenopausal Women

A double-blind, placebo-controlled once-daily oral dose of $2 \mathrm{MD}$ in postmenopausal women study was conducted to ascertain safety and efficacy. This study was conducted at a single US site (Comprehensive NeuroScience, Inc., Fort Lauderdale, Fla., USA). Subjects were assigned to 5 cohorts with 12 subjects in each group (8 2MD, 2 calcitriol and 2 placebo subjects/cohort). After the first cohort received 7 doses, laboratory data were reviewed and the second cohort initiated based on the safety information from the first cohort. All subsequent cohorts were begun after the first week of laboratory results were available from the preceding cohort. 64 postmenopausal women were enrolled and randomized to treatment; 4 subjects withdrew from the study ( 1 each from the placebo and $0.05-\mu \mathrm{g} 2 \mathrm{MD}$ groups and 2 from the $0.17-\mu \mathrm{g} 2 \mathrm{MD}$ group) resulting in 60 healthy postmenopausal women completing the trial in one of seven dose groups - placebo, $0.5 \mu \mathrm{g}$ calcitriol, 50, 110, 170,220 or $440 \mathrm{ng} 2 \mathrm{MD}(\mathrm{n}=8$ for each $2 \mathrm{MD}$ group and $\mathrm{n}=10$ for calcitriol and placebo groups). Dose administration occurred once daily in the form of gelatin capsules for 28 consecutive days. Total serum calcium, serum phosphorus, and iPTH were analyzed at screening, and baseline and 1, 3, 7, 14, and 28 days postdose initiation and 2 weeks after the dose was stopped. Plasma was also collected for pharmacokinetic measurements using HPLC in conjunction with a cell-based assay. This assay involved solid-phase extraction followed by HPLC separation of 2MD from other endogenous forms of vitamin $\mathrm{D}$ and then quantitation using a re- porter cell assay [27]. This trial has been registered at ClinicalTrials.gov (NCT01969656) was approved by the Independent Institutional Review Board (6738 West Sunrise Blvd, Suite 102, Plantation, FL 33313, USA), and was conducted in accordance with the Helsinki Declaration of 1975.

\section{Statistical Analysis}

All statistical analyses were done using the SAS mixed-model procedures with Dunnett's adjustment (SAS Institute, Inc., Cary, N.C., USA).

\section{Results}

It was unexpected to find that radioactive $2 \mathrm{MD}$ localized to the greatest extent in thyroid/parathyroid glands (fig. 1). As expected, intestine and bone, both well-known target organs of vitamin $\mathrm{D}$ action, did show localization of radioactive $2 \mathrm{MD}$, while a non-target tissue (e.g. heart) did not. Previously using a highly specific antibody, no VDR could be detected in either heart or skeletal muscle [28]. The low or basal level of radioactivity seen in the heart muscle (fig. 1) is found in all tissues and likely resulted from retained blood that contains ca. $10 \mathrm{pg} / \mathrm{ml}$ of $2 \mathrm{MD}$. By $72 \mathrm{~h}$ postdose, the radioactivity had essentially disappeared from all but three tissues.

The localization in the thyroid/parathyroid gland led us to consider that $2 \mathrm{MD}$ might have preferential action in the parathyroid gland to suppress synthesis and secretion of PTH. As with previous vitamin D compounds, the 5/6-nephrectomy rat model was used to test this hypothesis. A representation of several such experiments is shown in figure 2. A dose-dependent suppression of serum PTH was observed after both 4 and 8 weeks of dosing with $2 \mathrm{MD}$. A daily oral dose of $1 \mathrm{ng} / \mathrm{kg} \mathrm{bw} /$ day suppressed serum PTH by at least $35 \%$ without changing serum cal- 



Fig. 2. Serum PTH, calcium, and phosphorus levels in uremic rats treated either with $2 \mathrm{MD}(\mathbf{a}-\mathbf{c})$ or Zemplar ${ }^{\circledR}(\mathbf{d}-\mathbf{f})$. Each bar represents the mean \pm SEM of $8-13$ nephrectomized rats or 5 sham- operated rats. Asterisks indicate statistically significant differences compared to vehicle controls and plus signs are compared to sham controls. $\mathrm{p}<0.001$. 




Fig. 3. Bone mineral density (BMD) of uremic rats treated with $2 \mathrm{MD}$. Rats described in figure 2 were used to determine BMD. Asterisks indicate statistically significant differences from vehicle controls and plus signs are significant differences from sham controls. $\mathrm{p}<0.001$.

cium and phosphorus levels for as long as 8 weeks (fig. 2a). A dose of $2.5 \mathrm{ng} / \mathrm{kg}$ bw/day suppressed PTH maximally and within 4 weeks of dose initiation. Serum calcium levels remained unchanged until a dose of $5 \mathrm{ng} 2 \mathrm{MD} / \mathrm{kg}$ bw/ day was administered (fig. 2b). 2MD had little effect on serum phosphorus (fig. 2c), although a trend to lower values was noted in one study.

We tested Zemplar ${ }^{\circledR}$ (paricalcitol) in an identical or side-by-side comparison (fig. 2d-f). Significant PTH suppression occurred with a daily dose of $100 \mathrm{ng} / \mathrm{kg}$ bw/day and was accompanied by significant elevation of serum calcium compared to sham controls (fig. 2e). Thus, the effective dose of $2 \mathrm{MD}$ was 40 times less than Zemplar ${ }^{\circledR}$ and without serum calcium elevation.

Based on 2MD's strong potency in other models of bone disease [23], BMD was measured in the uremic rats at termination (8 weeks of daily oral $2 \mathrm{MD}$ administration) (fig. 3). As predicted from all rat models tested previously [23], 2MD not only prevented the loss of bone mineral density as a result of the nephrectomies but actually increased BMD above sham levels.

The effectiveness of $2 \mathrm{MD}$ in suppressing $\mathrm{PTH}$ in the human population was demonstrated in a previous study of postmenopausal women in which a dose of $220 \mathrm{ng} /$ day for 6 months caused a significant reduction of PTH [24]. In this population, three consecutive daily doses (110-440 ng) of $2 \mathrm{MD}$ caused a significant decrease in PTH (fig. 4a). PTH suppression is also apparent, although not statistically significant, 2 weeks after the last dose of $2 \mathrm{MD}$. This rapid and sustained effect is consistent with the pharmacokinetic profile observed in this same population of women (table 1). Although the plasma concentration-time data did not allow calculation of a terminal half-life in this study, a half-life of $\sim 24 \mathrm{~h}$ was estimated. No significant increases in serum calcium or phosphorus were noted at any dose level in this trial (fig. 4b, c). In this study, plasma $2 \mathrm{MD}$ was measured as a function of time following the last dose of $2 \mathrm{MD}$ (fig. 5). Because of its long half-life (table 1), plasma levels remained constant for $24 \mathrm{~h}$ after the last dose.

\section{Discussion}

The value of vitamin D-based therapy in dialysis patients is very clear from their increased survival [22] and the fact that the major, if not sole, source of $1,25-(\mathrm{OH})_{2} \mathrm{D}_{3}$, the active form of vitamin $\mathrm{D}$ is the kidney. Certainly the development of vitamin D therapy has progressed from the use of larger doses of vitamin D itself [1], to its first metabolite, 25-hydroxyvitamin $\mathrm{D}(3,4)$, and to the first use of oral $1,25-(\mathrm{OH})_{2} \mathrm{D}_{3}[10,11]$. Unfortunately in chronically orally dosed animals, $1,25-(\mathrm{OH})_{2} \mathrm{D}_{3}$ loses its effectiveness because $1,25-(\mathrm{OH})_{2} \mathrm{D}_{3}$ induces CYP24A1 [29-31] in the intestine that then destroys $1,25-(\mathrm{OH})_{2} \mathrm{D}_{3}$ as it is absorbed [32], limiting its impact on internal targets such as the parathyroid gland. By providing vitamin D compounds that are 1-hydroxylated but lack the 25-hydroxyl, orally administered analogs are unable to induce CYP24A1 in the intestine as it is absorbed. Once in the circulation, these analogs are 25 -hydroxylated in the liver, giving rise to the hormonal form that can then act to suppress the parathyroid gland. Thus, $1 \alpha$-hydroxyvitamin $\mathrm{D}_{2}$ and 1 $1 \alpha$-hydroxyvitamin $\mathrm{D}_{3}$ have been successfully applied in the USA as Hectorol ${ }^{\circledR}$ and elsewhere as Alfarol ${ }^{\circledR}$ and 1 Alpha, etc. $[18,19]$, resulting in a definitive improvement over oral $1,25-(\mathrm{OH})_{2} \mathrm{D}_{3}$ (Rocaltrol $\left.{ }^{\circledR}\right)$. The provision of $1,25-(\mathrm{OH})_{2} \mathrm{D}_{3}$ in an injectable form (Calcijex ${ }^{\circledR}$ ) was also an improvement by avoiding stimulating CYP24A1 in the intestine and first-pass effect in intestinal absorption of calcium and phosphate [32]. However, the dose range before unwanted hypercalcemia remained small, giving nephrologists the difficult task of adjusting the dose [17]. The introduction of two analogs with reduced calcemic activity (i.e. 22-oxa (OCT) and Zem- 
Fig. 4. Serum PTH (a), serum calcium (b), and serum phosphorus (c) levels in postmenopausal women after 28 days of oncedaily $2 \mathrm{MD}$ administration and 2 weeks after discontinuation of treatment. Each data point represents the mean \pm SD of $8-10$ women. All but the lowest dose showed a statistically significant suppression after 3 days $(\mathrm{p}<0.05)$. The highest dose group, $440 \mathrm{ng} 2 \mathrm{MD}$, showed statistically lower values at all time points except at day 42. p < 0.01 .

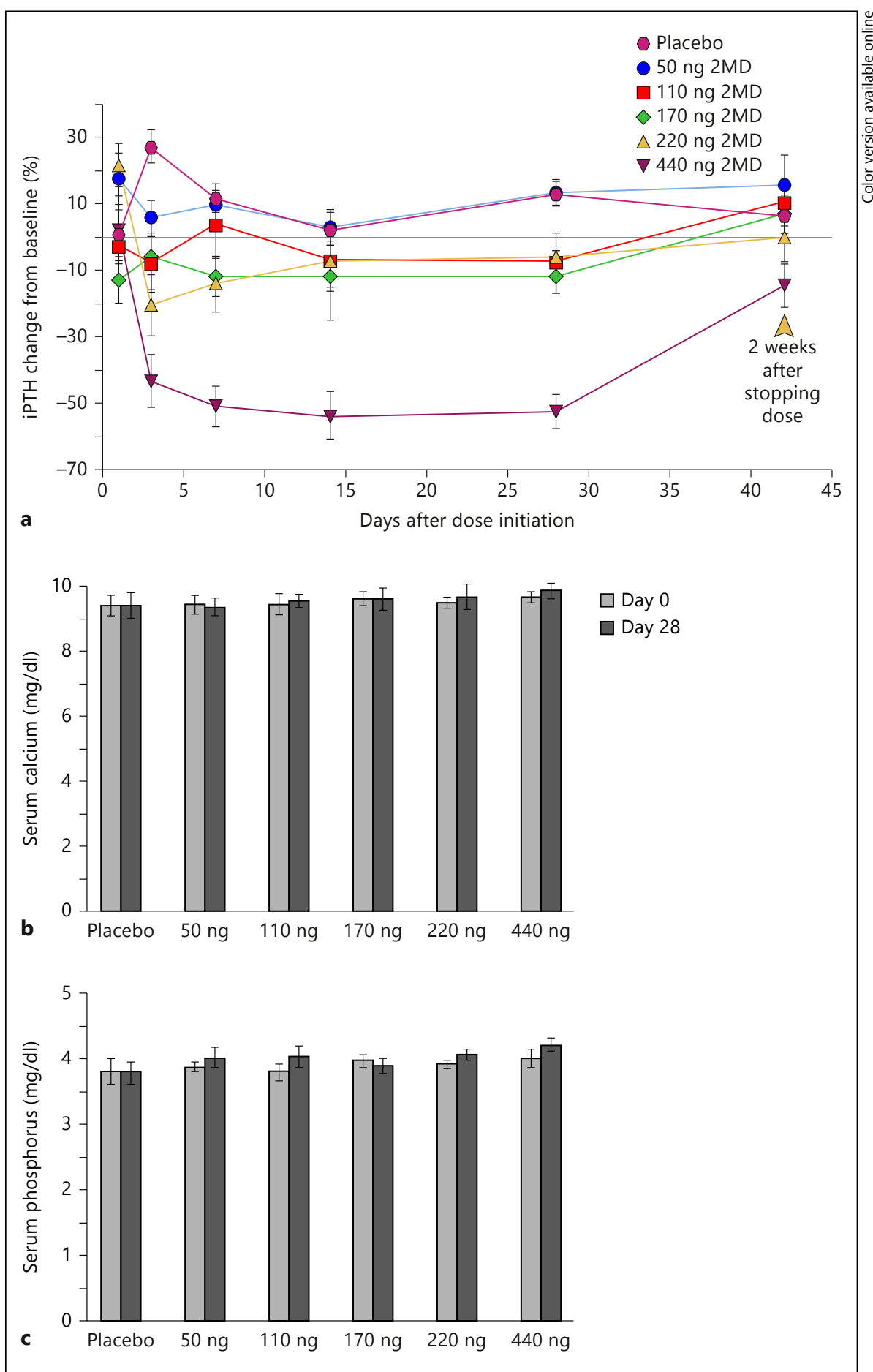

plar $^{\circledR}$ ) was a further improvement in dialysis therapy [20, 21]. Because of their short half-lives in vivo, the 3 times/ week doses needed were fairly high, and the range of effectiveness prior to hypercalcemia remained narrow. The introduction of calcium mimetics seemed to provide the needed safety margin to the current vitamin $\mathrm{D}$ therapies [33], but with a considerable increase in expense and further complication of adjusting the dose of two drugs and an increased risk of side effects. Further, the calcium mimetics did not appear to increase survival of dialysis pa- 
Fig. 5. Time course of plasma $2 \mathrm{MD}$ concentrations after 28 days of once-daily oral administration in postmenopausal women. Each bar represents the mean \pm SD of 8-10 women.

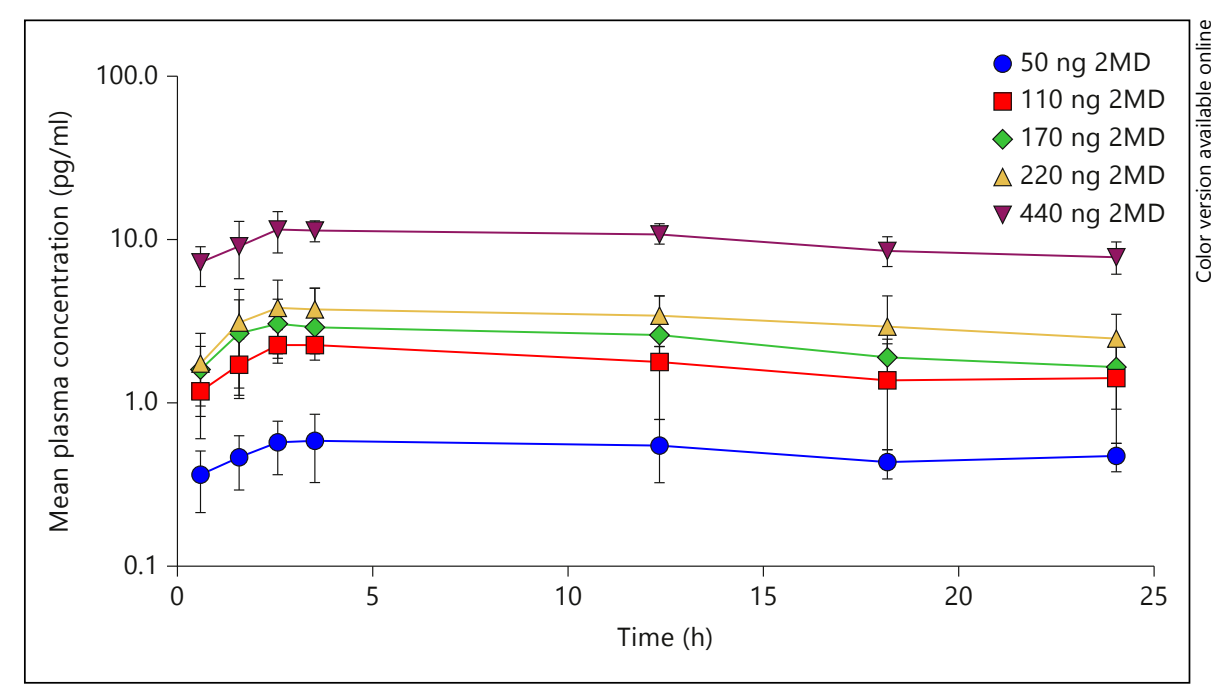

Table 1. Mean pharmacokinetic parameters following multiple (28 consecutive) once-daily oral doses of $2 \mathrm{MD}^{\mathrm{a}}$

\begin{tabular}{llrll}
\hline $\begin{array}{l}\text { Dose level } \\
\text { ng/day }\end{array}$ & $\begin{array}{l}\mathrm{C}_{\max } \\
\mathrm{pg} / \mathrm{ml}\end{array}$ & \multicolumn{1}{l}{$\begin{array}{l}\mathrm{T}_{\max } \\
\mathrm{h}\end{array}$} & $\begin{array}{l}\mathrm{C}_{\min }{ }^{\mathrm{b}} \\
\mathrm{pg} / \mathrm{ml}\end{array}$ & $\begin{array}{l}\mathrm{AUC}_{0-24} \\
\mathrm{pg} \cdot \mathrm{h} / \mathrm{ml}\end{array}$ \\
\hline 50 & $0.66 \pm 0.2$ & $12(2-24)$ & $0.47 \pm 0.1^{\mathrm{c}}$ & $11.8 \pm 3.8$ \\
110 & $2.6 \pm 0.3$ & $3(2-12)$ & $1.4 \pm 0.9$ & $41.2 \pm 18$ \\
170 & $3.7 \pm 1.2$ & $2.5(1-12)$ & $1.7 \pm 0.8$ & $57.0 \pm 14$ \\
220 & $4.3 \pm 1.7$ & $3(1-12)$ & $2.5 \pm 0.9$ & $76.9 \pm 29$ \\
440 & $12.5 \pm 2.3$ & $2.5(2-12)$ & $7.9 \pm 1.7$ & $236 \pm 35$ \\
\hline
\end{tabular}

$\mathrm{C}_{\max }=$ Maximum observed plasma concentration; $\mathrm{T}_{\max }=$ time of $\mathrm{C}_{\max } ; \mathrm{C}_{\min }=$ minimum observed plasma concentration; $\mathrm{AUC}_{0-24}=$ area under the plasma concentration curve hours 0-24.

${ }^{a}$ Values are mean values $\pm S D$ except for $T_{\max }$, which is median (range); $\mathrm{n}=8 ;{ }^{\mathrm{b}} \mathrm{C}_{\min }$ defined as plasma $2 \mathrm{MD}$ concentration at time $=24$ h on day $28 ;{ }^{c} n=7$ due to insufficient sample volume from 1 subject at time $=24 \mathrm{~h}$.

tients [34]. It is clear that there is a need for improved therapies for osteodystrophy and secondary hyperparathyroidism in dialysis patients.

In our continuing search for analogs that have selective activity, we prepared an analog that differs from $1,25-(\mathrm{OH})_{2} \mathrm{D}_{3}$ in three ways. Firstly, we introduced an inversion in stereochemistry at the 20-position; secondly, we eliminated the 10,19-methylene group, and thirdly, we introduced a methylene group on carbon-2 [35]. The result, $2 \mathrm{MD}$ proved to be the most potent form of vitamin D but most importantly, selective for bone by 30 - to 100 fold [23]. Unexpectedly, it is also selective for the parathyroid gland (fig. 2) and potently suppresses serum PTH
[24]. This property and its slow rate of metabolism by CYP24A1 [36] immediately suggested it as a candidate for the treatment of secondary hyperparathyroidism of renal failure.

The entry preclinical bioassay for candidate drugs to control secondary hyperparathyroidism is the 5/6-nephrectomy rat model that successfully predicted the value of Calcijex ${ }^{\circledR}, 22$-Oxa and Zemplar ${ }^{\circledR}[17,20,21,37]$. The result of this bioassay for $2 \mathrm{MD}$ clearly demonstrates its potency and shows a wider therapeutic window than one of the market leaders, Zemplar ${ }^{\circledR}$ (i.e. target efficacy without hypercalcemia). It also acts rapidly and is a osteoanabolic agent, which suggests it is likely to improve the skeleton of dialysis patients. Although the present results suggest excellent promise, its value in dialysis patients must await results from phase 2 trials currently in progress and beyond.

\section{Acknowledgements}

This work was supported in part by a fund from the Wisconsin Alumni Research Foundation and a grant from Deltanoid Pharmaceuticals, Inc. The WBAL study and PK analyses were conducted by Pfizer, Inc., Department of Pharmacokinetics, Dynamics and Metabolism, Groton, Conn., USA. Many thanks to all the technical staff for the preparation and care of the uremic rats, including Xiahong Ma, Shinobu Miyasaki, Jennifer Vaughan, William Blaser.

\section{Disclosure Statement}

J.B. Zella, L.A. Plum, M. Clagett-Dame, and H.F. DeLuca have a financial interest in Deltanoid Pharmaceuticals, Inc. that is developing $2 \mathrm{MD}$ as a pharmaceutical. 


\section{References}

1 Lumb GA, Mawer EB, Stanbury SW: The apparent vitamin $\mathrm{D}$ resistance of chronic renal failure. A study of the physiology of vitamin D in man. Am J Med 1971;50:421-441.

2 Blunt JW, DeLuca HF, Schnoes HK: 25-Hydroxycholecalciferol. A biologically active metabolite of vitamin $\mathrm{D}_{3}$. Biochemistry 1968 ; 7:3317-3322.

3 DeLuca HF, Avioli LV: Treatment of renal osteodystrophy with 25-hydroxycholecalciferol. Arch Intern Med 1970;126:896-898.

$\checkmark 4$ Witmer C, Margolis A, Fontaine O, Fritsch J, Lenoir G, Broyer M, Balsan S: Effects of 25-hydroxycholecalciferol on bone lesions of children with terminal renal failure. Kidney Int 1976;10:395-408.

5 Holick MF, Schnoes HK, DeLuca HF, Suda T, Cousins RJ: Isolation and identification of 1,25-dihydroxycholecalciferol. A metabolite of vitamin $\mathrm{D}$ active in intestine. Biochemistry 1971;10:2799-2804.

-6 Fraser DR, Kodicek E: Unique biosynthesis by kidney of a biologically active vitamin D metabolite. Nature 1970;228:764-766.

7 Gray R, Boyle I, DeLuca HF: Vitamin D metabolism: the role of kidney tissue. Science 1971;172:1232-1234.

8 Boyle IT, Miravet L, Gray RW, Holick MF, DeLuca HF: The response of intestinal calcium transport to 25-hydroxy and 1,25-dihydroxy vitamin D in nephrectomized rats. Endocrinology 1972;90:605-608.

9 Holick MF, Garabedian M, DeLuca HF: 1,25-Dihydroxycholecalciferol: metabolite of vitamin $\mathrm{D}_{3}$ active on bone in anephric rats. Science 1972;176:1146-1147.

10 Silverberg DS, Bettcher KB, Dossetor JB, Overton TR, Holick MF, DeLuca HF: Effect of 1,25-dihydroxycholecalciferol in renal osteodystrophy. Can Med Assoc J 1975;112:190-195.

11 Brickman AS, Coburn JW, Friedman GR, Okamura WH, Massry SG, Norman AW: Comparison of effects of $1 \alpha$-hydroxy-vitamin $\mathrm{D}_{3}$ and 1,25-dihydroxy-vitamin $\mathrm{D}_{3}$ in man. J Clin Invest 1976;57:1540-1547.

$\$ 12$ Brumbaugh PF, Haussler MR: Specific binding of 1a,25-dihydroxycholecalciferol to nuclear components of chick intestine. J Biol Chem 1975;250:1588-1594.

13 Kream BE, Reynolds RD, Knutson JC, Eisman JA, DeLuca HF: Intestinal cytosol binders of 1,25-dihydroxyvitamin $\mathrm{D}_{3}$ and 25-hydroxyvitamin $D_{3}$. Arch Biochem Biophys 1976;176: 779-787.

14 Demay MB, Kiernan MS, DeLuca HF, Kronenberg M: Sequences in the human parathyroid hormone gene that bind the 1,25-dihydroxyvitamin $\mathrm{D}_{3}$ receptor and mediate transcriptional repression in response to 1,25-dihydroxyvitamin $\mathrm{D}_{3}$. Proc Natl Acad Sci USA 1992;89:8097-8101.
15 Silver J, Naveh-Many T: Vitamin D and the parathyroids; in Feldman D, Pike JW, Glorieux FH (eds): Vitamin D. Burlington/MA, Elsevier Academic Press, 1997, chapt 23, pp 537-549.

16 Slatopolsky E, Brown A, Dusso A: Calcium, phosphorus and vitamin $\mathrm{D}$ disorders in uremia. Contrib Nephrol. Basel, Karger, 2005, vol 149, pp 262-271.

17 Slatopolsky E, Weerts C, Theilan J, Horst R, Harter H, Martin KJ: Marked suppression of secondary hyperparathyroidism by intravenous administration of 1,25-dihydroxycholecalciferol in uremic patients. J Clin Invest 1984;74:2136-2143.

$>18$ Chan JCM, Oldham SB, DeLuca HF: Effectiveness of $1 \alpha$-hydroxyvitamin $\mathrm{D}$ in children with renal osteodystrophy associated with hemodialysis. J Pediatrics 1977;90:820-824.

19 Brown AJ, Ritter C, Knutson JC, Strugnell SA: The vitamin D prodrugs $1 \alpha(\mathrm{OH}) \mathrm{D}_{2}, 1 \alpha(\mathrm{OH})$ $\mathrm{D}_{3}$ and BCI-210 suppress PTH secretion by bovine parathyroid cells. Nephrol Dial Transplant 2006;21:644-650

20 Slatopolsky E, Finch J, Ritter C, Denda M, Morrissey J, Brown A, DeLuca H: A new ana$\log$ of calcitriol, 19-nor-1,25- $(\mathrm{OH})_{2} \mathrm{D}_{2}$, suppresses parathyroid hormone secretion in uremic rats in the absence of hypercalcemia. Am J Kidney Dis 1995;26:852-860.

21 Finch JL, Brown AJ, Mori T, Nishii Y, Slatopolsky E: Suppression of PTH and decreased action on bone are partially responsible for the low calcemic activity of 22-oxacalcitriol relative to $1,25-(\mathrm{OH})_{2} \mathrm{D}_{3}$. J Bone Miner Res 1992; 7:229-233.

22 Teng M, Wolf M, Lowrie E, Ofsthun N, Lazarus JM, Thadhani R: Survival of patients undergoing hemodialysis with paricalcitol or calcitriol therapy. N Engl J Med 2003;349: 446-456.

23 Shevde NK, Plum LA, Clagett-Dame M, Yamamoto H, Pike JW, DeLuca HF: A potent analog of $1 \alpha, 25$-dihydroxyvitamin $\mathrm{D}_{3}$ selectively induces bone formation. Proc Natl Acad Sci USA 2002;99:13487-13491.

24 DeLuca HF, Bedale W, Binkley N, Gallagher JC, Bolognese M, Peacock M, Aloia J, ClagettDame M, Plum L: The vitamin D analogue 2MD increases bone turnover but not BMD in postmenopausal women with osteopenia: results of a 1-year phase 2 double-blind, placebo-controlled, randomized clinical trial. J Bon Miner Res 2011;26:538-545.

25 Potchoiba MJ, Tensfeldt TG, Nocerini MR, Silber BM: A novel quantitative method for determining the biodistribution of radiolabeled xenobiotics using whole-body cryosectioning and autoradioluminography. J Pharmacol Exp Ther 1995;272:953-962.

-26 Potchoiba MJ, West M, Nocerini MR: Quantitative comparison of autoradioluminographic and radiometric tissue distribution studies using carbon-14 labeled xenobiotics. Drug Metab Dispos 1998;26:272-277.
27 Arbour NC, Ross TK, Zierold C, Prahl JM, DeLuca HF: A highly sensitive method for large-scale measurements of 1,25-dihydroxyvitamin D. Analyt Biochem 1998;255: 148-154.

28 Wang Y, DeLuca HF: Is the vitamin D receptor found in muscle? Endocrinology 2011; 152:354-363.

29 Jones G, Strugnell SA, DeLuca HF: Current understanding of the molecular actions of vitamin D. Physiol Rev 1998;78:1193-1231.

30 Beckman MJ, Tadikonda P, Werner E, Prahl J, Yamada S, DeLuca HF: The human 25-hydroxyvitamin $\mathrm{D}_{3}-24$-hydroxylase, a multicatalytic enzyme. Biochemistry 1996;35:84658472.

31 Endres B, Kato S, DeLuca HF: Metabolism of 1a,25-dihydroxyvitamin $\mathrm{D}_{3}$ in vitamin $\mathrm{D}$ receptor ablated mice in vivo. Biochemistry 2000;39:2123-2129.

32 Frolik CA, DeLuca HF: The stimulation of 1,25-dihydroxycholecalciferol metabolism in vitamin $\mathrm{D}$-deficient rats by 1,25 -dihydroxycholecalciferol treatment. J Clin Invest 1973; 52:543-548.

33 Block GA, Martin KJ, de Francisco AL, Turner SA, Avram MM, Suranyi MG, Hercz G Cunningham J, Abu-Alfa AK, Messa $P$, Coyne DW, Locatelli F, Cohen RM, Evenepoel P, Moe SM, Fournier A, Braun J, McCary LC, Zani VJ, Olson KA, Drüeke TB, Goodman WG: Cinacalcet for secondary hyperparathyroidism in patients receiving hemodialysis. N Engl J Med 2004;350:15161525.

- 34 Chertow GM, Block GA, Correa-Rotter R, Drüeke TB, Floege J, Goodman WG, Herzog CA, Kubo Y, London GM, Mahaffrey KW, Mix TC, Moe SM, Trotman ML, Wheeler DC, Parfrey PS: Effect of cinacalcet on cardiovascular disease in patients undergoing dialysis. N Engl J Med 2012;367:2482-2494.

35 Sicinski RR, Prahl JM, Smith CM, DeLuca HF: New 1a,25-dihydroxy-19-norvitamin $\mathrm{D}_{3}$ compounds of high biological activity: synthesis and biological evaluation of 2-hydroxymethyl, 2-methyl and 2-methylene analogs. J Med Chem 1998;41:4662-4674.

36 Zhu J, Barycki R, Chiellini G, DeLuca HF: Screening of selective inhibitors of $1 \alpha, 25$ dihydroxyvitamin $\mathrm{D}_{3}$ 24-hydroxylase using recombinant human enzyme expressed in Escherichia coli. Biochemistry 2010;49: 10403-10411.

37 Brown AJ, Ritter CR, Finch H, Morrissey J, Martin KJ, Murayama E, Nishii Y, Slatopolsky E: The noncalcemic analog of vitamin D, 22-oxacalcitriol, suppresses parathyroid hormone synthesis and secretion. J Clin Invest 1989;84:728-732. 